\title{
Motivating Factors of Informal Trade in Intermediate Cities of Ecuador: Application of the Factorial Model
}

\author{
Gabith Quispe Fernandez ${ }^{1,2}$, Dante Ayaviri Nina ${ }^{2,3}$, Marlon Villa Villa ${ }^{1}$, Rodrigo Velarde Flores ${ }^{1}$ \& \\ Marieta Tapia Muñoz ${ }^{3}$ \\ ${ }^{1}$ School Accounting and Auditing, National University of Chimborazo, Ecuador \\ ${ }^{2}$ School of Business Administration, Technical University of Oruro, Bolivia \\ ${ }^{3}$ Commercial Engineering and Economics School, National University of Chimborazo, Ecuador \\ Correspondence: Dante Ayaviri Nina, Campus Norte “Edison Riera R.”, Av. Antonio José de Sucre Km 1 1/2 vía \\ Guano, Riobamba city, Ecuador. E-mail: vdayaviri@gmail.com
}

Received: December 21, 2019

doi:10.5539/ies.v13n8p42
Accepted: February 28, $2020 \quad$ Online Published: July 23, 2020

URL: https://doi.org/10.5539/ies.v13n8p42

\begin{abstract}
This research aims to identify the motivating factors that influence the development of informal trade by merchants in the Republic of Ecuador. For this, the inductive method, at causal-statistical level, is applied; making use of a questionnaire as an information collection tool, with a sample of 310 informal merchants from a population of 3,600 located in the city of Riobamba. Factor analysis and linear regression are used. Results show that informal activity is related to unemployment, independence and necessity; being that informal trade depends on age, marital status, ethnicity, area, economic income, location, need, and lack of knowledge about public spaces and taxation regulations.
\end{abstract}

Keywords: motivation, commerce, informality, cities, merchant

\section{Introduction}

Research on informal activity, such as the International Labour Organization (ILO), OIT (2002, 2014, 2016, 2019), ILO (2012, 2014), World Bank $(2013,2019)$ and others, show that "informal workers routinely face higher risks of poverty than workers of the formal economy and that informal economy work, poverty, and vulnerability are highly related" quoted in Quispe et al. $(2018$, p. 4). Thus, informality is understood as "a phenomenon that some years ago was considered a particular feature of some economies, especially in backward economies, which existence overflowed the archetype of how modern economies should work" (Sandoval, 2014, p. 11). Data show that unemployment rate according to the ILO, reaches 9.9\% in Latin America for 2017, in the case of Ecuador $4.3 \%$ (OIT, 2018, p. 7). Thus, employability indicators in Ecuador show that the activity in the informal sector reaches $47.5 \%$, unlike the formal sector, reaching 46\%; these and other indicators are displayed in Figure 1. 


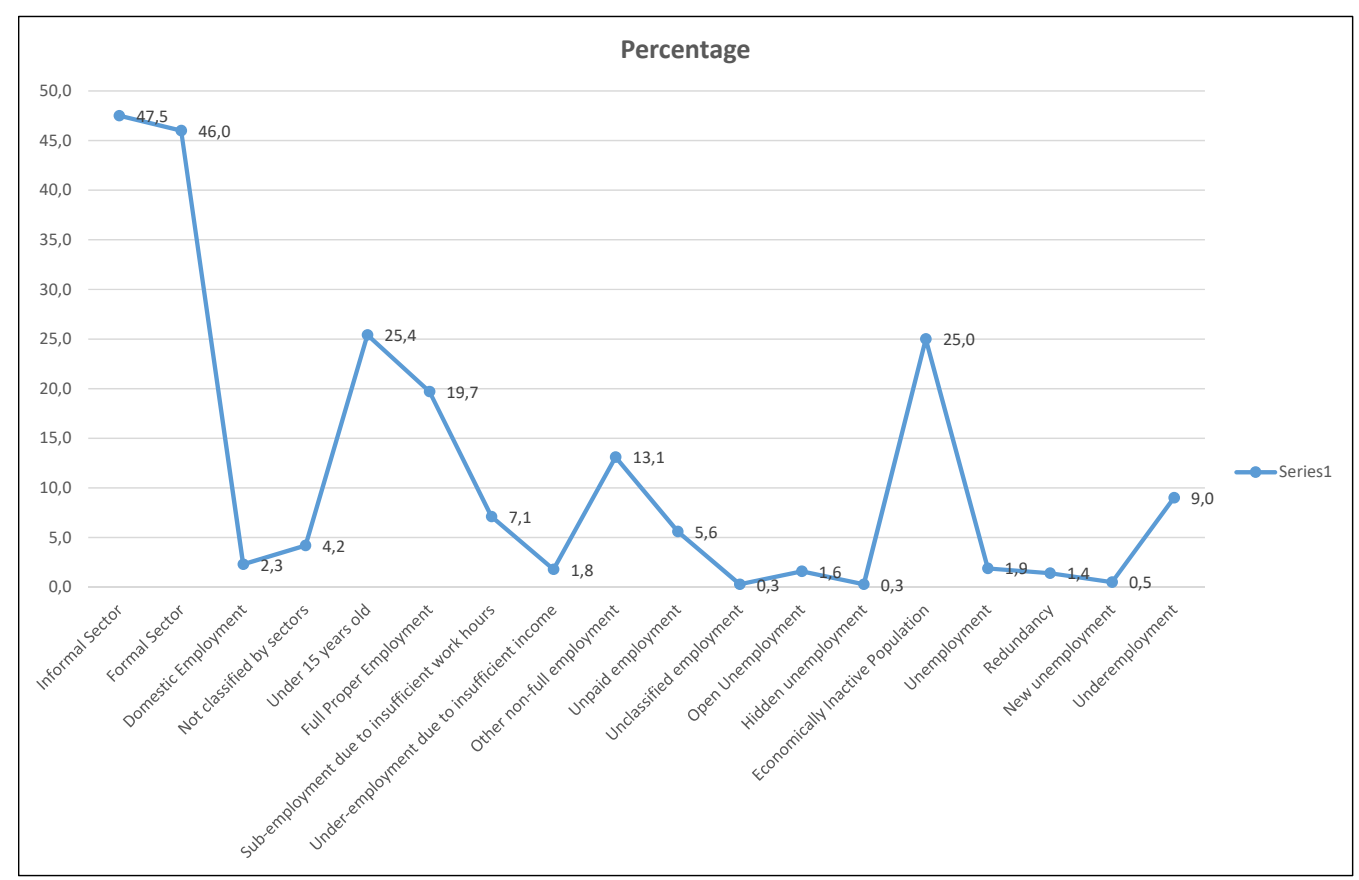

Figure 1. Employability indicators in Ecuador

Source: Own elaboration based on (ENEMDU, INEC, 2018)

Likewise, the data show that trade is a formal activity with a high participation in the labour market, as seen in Table 1, where for example in 2016, it represents $32.3 \%$, followed by communal, social and personal service activities, representing $22.1 \%$ (OIT, 2018). However, this formal activity has been facing a series of economic and social problems, since the informal trade sector has increased in different countries, mainly in Ecuador, especially around local markets in cities. According to data collected in this research, it is seen that-in no more than two years-around 200 more people started activities as merchants in close-by areas to markets, without neglecting the presence of sale-points in different streets of the cities, mainly offering agricultural and clothing products.

Table 1. Activities developed by the economic population-Ecuador

\begin{tabular}{|c|c|c|c|c|c|c|c|c|c|c|}
\hline $\begin{array}{c}\text { Countries, } \\
\text { years and } \\
\text { gender }\end{array}$ & Total & $\begin{array}{c}\text { Agriculture, } \\
\text { fishing, and } \\
\text { mining }\end{array}$ & $\begin{array}{c}\text { Electricity, } \\
\text { gas and } \\
\text { water }\end{array}$ & $\begin{array}{c}\text { Manufacturing } \\
\text { industry }\end{array}$ & Construction & Commerce & $\begin{array}{c}\text { Transport, } \\
\text { storage, and } \\
\text { communications }\end{array}$ & $\begin{array}{l}\text { Financial } \\
\text { institutions }\end{array}$ & $\begin{array}{c}\text { Communal, } \\
\text { social, and } \\
\text { personal } \\
\text { services }\end{array}$ & $\begin{array}{c}\text { Non } \\
\text { specified } \\
\text { activities }\end{array}$ \\
\hline 2011 Total & 100 & 8.1 & 0.6 & 13.2 & 6.7 & 34.1 & 8.1 & 7.7 & 21.5 & 0 \\
\hline Man & 100 & 11.2 & 0.8 & 14.1 & 10.8 & 28 & 11.8 & 8.2 & 15 & 0 \\
\hline Woman & 100 & 3.7 & 0.3 & 11.8 & 0.9 & 42.9 & 2.8 & 6.9 & 30.8 & 0 \\
\hline 2012 Total & 100 & 7.6 & 0.6 & 12.9 & 6.9 & 33.9 & 8 & 8.6 & 21.6 & 0 \\
\hline Man & 100 & 10.3 & 0.8 & 14.1 & 11 & 27.3 & 12.2 & 9.5 & 14.8 & 0 \\
\hline Woman & 100 & 3.9 & 0.3 & 11.3 & 1 & 43.1 & 2.2 & 7.3 & 30.9 & 0 \\
\hline 2013 Total & 100 & 7.8 & 0.6 & 13.3 & 8.1 & 30.1 & 8.4 & 8.2 & 23.5 & 0 \\
\hline Man & 100 & 10.4 & 0.7 & 14.4 & 13 & 24.6 & 12.4 & 8.2 & 16.6 & 0 \\
\hline Woman & 100 & 3.9 & 0.4 & 11.7 & 0.9 & 38.1 & 3 & 8.2 & 33.8 & 0 \\
\hline 2014 Total & 100 & 9 & 0.6 & 12.6 & 7.6 & 31.2 & 8.7 & 7.2 & 23.2 & 0 \\
\hline Man & 100 & 11.7 & 0.7 & 14.4 & 12.5 & 24.6 & 12.5 & 7.8 & 15.8 & 0 \\
\hline Woman & 100 & 5 & 0.3 & 10.1 & 0.5 & 40.7 & 3.1 & 6.4 & 34 & 0 \\
\hline 2015 Total & 100 & 8.6 & 0.6 & 12.2 & 8 & 31.5 & 9.2 & 7.3 & 22.7 & 0 \\
\hline Man & 100 & 11.5 & 0.9 & 13.3 & 12.9 & 24.8 & 13.5 & 7.5 & 15.3 & 0 \\
\hline Woman & 100 & 4.4 & 0.2 & 10.3 & 0.8 & 41 & 3 & 7 & 33.2 & 0 \\
\hline 2016 Total & 100 & 8.8 & 0.6 & 12.9 & 7.9 & 32.3 & 8.4 & 6.9 & 22.1 & 0 \\
\hline
\end{tabular}




\begin{tabular}{cccccccccccc}
\hline Man & 100 & 11.3 & 0.9 & 14.5 & 13.1 & 25 & 12.7 & 7.4 & 14.9 & 0 \\
\hline Woman & 100 & 5.4 & 0.2 & 10.7 & 0.7 & 42.4 & 6.1 & 6.1 \\
\hline
\end{tabular}

Source: Own elaboration based on ILO data, 2018.

From this perspective, informal trade is a serious problem for the formal commerce sector. Therefore, the investigation begins with the following questions: What motivational factors influence the development of informal trade by merchants? and What are the factors that explain the how, the type, and the way to develop this activity in intermediate cities?

After conducting a bibliographic tour, different studies were identified, such as, Sandoval (2014); Moreira and Pilco (2016); Romero et al. (2018); Boza (2018); Adasme (2017); Martínez et al. (2019)-identifying some characteristics and causes for informality; likewise, there are some exclusively related to the measurement of variables that explain the coincidences of informality and informal trade, such as, Jiménez and Martinéz-Pardo (2013), Sandoval (2014); Villamil (2014), Moreira and Pilco (2016), Romero (2018), Villamil (2014); Rodríguez, De la Torre, and Regla (2016), Martínez et al. (2019), and also the identification of causes and their relationship with tax evasion Quispe et al. (2018), Teja and Lopez (2013) among other studies on informality. However, there are few studies on informal trade in Ecuador, mainly for the city of Riobamba, such as De Souza and Bustos (2017), Moreira and Pilco (2016), and Quispe et al. (2018).

Thus, the study becomes relevant, since, from the theoretical point of view, it considers informal economy as an informal activity linked to informal trade, understanding that informal trade "is not governed by the goods/services transaction regulations and laws. Informal commerce, done in streets and public spaces, on the basis of merchandise, usually at low cost and very dynamic in terms of offer, has become the central activity where thousands of people act" (Castillo-Garcia, 2014, p. 4). Likewise, "informal activities reduce the tax base, thereby preventing sustainable financing of public goods and social protection ... a high dimension of the informal sector tends to negatively affect the evolution of the economic activity" (Hernandez \& De la Roca, 2006, p. 65). This means that informal trade does not only affect informal trade income, but also tax evasion; understanding that tax evasion is an illegal action, that is, violation of the tax law (its letter and spirit). Therefore, tax evasion has a series of legal consequences for evaders, since it implies the transgression of the current tax legislation. To achieve this purpose, among other things, taxpayers make a false statement or simply hide tax information on their declarations and amount of the tax to be paid to the tax authority, as mentioned (Yañez, 2015).

Evasion occurs when an individual, a taxpayer, after having carried out operations involving the accusation and payment of a tax, refrains from complying with it. "This is in violation of the law, since the obligation exists, it has been given, and the individual does not comply with it" (Ochoa, 2014), so also, it is the "unlawful conduct for the concealment of all or part of the taxable transaction, done by the taxpayer to avoid paying the tax debt, being bound by the law (Rua, 2016). Therefore, tax evasion results into income decreasing, fiscal deficit and private investment reduction. In Ecuador, there are collection gaps based on comparative analyses of total tax due and generated taxes, calculated from national accounts, being evasion from natural persons the widest gap; information connected to tax culture level and evasion controls done by the Tax Administration of Ecuador (Ordóñez, 2010).

Based on above-mentioned facts, the research aims to identify the motivating factors that influence the development of informal trade by merchants in the Republic of Ecuador. Although different studies analysed the factors that motivate informality, this study, based on the identification of factors that motivate informal commerce in the city of Riobamba, seeks to determine whether there are differences between motivating factors identified in metropolitan cities and those in an intermediate city.

In this context, hypotheses to be addressed are: $\mathrm{H} 1=$ reasons traders have to start an informal activity is connected to unemployment, independence and necessity; $\mathrm{H} 2$ = age, marital status, ethnicity, area, economic income, location, need, lack of knowledge about regulations for public spaces use, and taxes, are motivational factors that influence informal trade; $\mathrm{H} 3$ = the type and form of informal trade activity does not depend on age, marital status, ethnicity, area, economic income, location, need, lack of knowledge about regulations for public spaces use, and taxes; $\mathrm{H} 4$ = informal trade activity depends on demographic, geographical, economic, availability, social, regulatory and commercialization factors, but not the type, or the form; H5 = there are no significant differences with the motivational factors identified in metropolitan cities compared to an intermediate city.

\section{Methodology}

The research, using the inductive method, is of a causal - statistical level. It uses the interview for information collection as well as the interview guide as information collection tool. The interview guide uses the informal 
economy questionnaires applied by the INEC and adapted to informal trade cases. A sample of 310 merchants from a population of 3,600 is used. Information is collected from merchants who do not have permanent points of sale and who carry out their commercial activity around the 10 markets of the city of Riobamba in 2019 year. The data shows a Crombach's alpha index of 0.768. For data analysis, multivariate factorization and linear regression analysis is used.

Variables considered for the factorial model and linear regression are based on the different motivating factors that influence the development of informal trade in metropolitan and intermediate cities - identified by different authors, as those presented in Table 2.

Table 2. Motivating factors identified by different authors

\begin{tabular}{|c|c|c|}
\hline Authors & Factors & Settings \\
\hline Robles \& Martinez (2018) & $\begin{array}{l}\text { - } \\
\text { - } \\
\text { - } \quad \text { Dichotinuous variables: Age to work, schooling, income. } \\
\text { medical care); People who have had a health problem, preventing } \\
\text { them from performing their daily activities; no trust in the } \\
\text { health-care unit. } \\
\text { Marital status: Marital status of the household member of } 12 \text { or } \\
\text { more years. } \\
\text { Gender: Biological distinction that classifies people into men and } \\
\text { women }\end{array}$ & $\begin{array}{l}\text { Urban - metropolitan } \\
\text { cities (Mexico) }\end{array}$ \\
\hline $\begin{array}{l}\text { Hirschman (1970, p., 246) quoted in } \\
\text { Robles \& Martinez (2018, p. 9) }\end{array}$ & Dissatisfaction with the organization they belong. & $\begin{array}{l}\text { Urban settings - } \\
\text { metropolitan cities } \\
\text { (Mexico) }\end{array}$ \\
\hline $\begin{array}{l}\text { De Soto (1989) quoted in Robles \& } \\
\text { Martine }(2018, \text { p. 9) }\end{array}$ & $\begin{array}{l}\text { It is not because of the barriers to entering the formal market, but } \\
\text { because of State inability to provide solution to their needs. }\end{array}$ & $\begin{array}{l}\text { Urban settings - } \\
\text { metropolitan cities } \\
\text { (Mexico) }\end{array}$ \\
\hline $\begin{array}{l}\text { Cunningham (2001) and Maloney } \\
\text { (1999) quoted in Robles \& Martinez } \\
(2018 \text {, p. 11) }\end{array}$ & $\begin{array}{l}\text { For pleasure, for the advantages of working in this market. } \\
\text { for the expectation of obtaining greater income in the } \\
\text { short-term and autonomy to be part of this sector. }\end{array}$ & $\begin{array}{l}\text { Urban settings - } \\
\text { metropolitan cities } \\
\text { (Mexico) }\end{array}$ \\
\hline $\begin{array}{l}\text { Levy (2008) quoted in (Robles \& } \\
\text { Martinez, 2018, p. 11) }\end{array}$ & Will and pleasure & $\begin{array}{l}\text { Urban settings - } \\
\text { metropolitan cities } \\
\text { (Mexico) }\end{array}$ \\
\hline $\begin{array}{l}\text { Mingione (1988); Gershuny (1988); } \\
\text { Carnoy (2000) quoted in Alvarez, } \\
\text { Goméz, Manjarrez, Orozco, \& Padilla } \\
(2015, \text { p. } 7)\end{array}$ & $\begin{array}{l}\text { Machine replacement } \\
\text { Difficult requirements to comply with the formality. }\end{array}$ & $\begin{array}{l}\text { Urban settings - } \\
\text { metropolitan cities } \\
\text { (Brazil) }\end{array}$ \\
\hline Quejada, Yanez, \& Cano (2014) & $\begin{array}{l}\text { - } \\
\text { - } \quad \text { Socio-demographic factors: Educational level, Gender. } \\
\text { Economic factors: globalization, industrial development, economic } \\
\text { cycle, real exchange rate. } \\
\text { - Institutional factors: labour market regulation. }\end{array}$ & $\begin{array}{l}\text { Urban settings - } \\
\text { metropolitan cities } \\
\text { (Colombia) }\end{array}$ \\
\hline $\begin{array}{l}\text { Bustamante, Díaz, \& Villareal (2009, p. } \\
54)\end{array}$ & $\begin{array}{l}\text { - } \quad \text { Under employment } \\
\text { - Income decreased }\end{array}$ & $\begin{array}{l}\text { Urban settings - } \\
\text { intermediate cities } \\
\text { (Chile) }\end{array}$ \\
\hline Teja \& López (2013) & $\begin{array}{ll}\text { - } & \text { Lack of employment } \\
\text { - } & \text { Income increase } \\
\text { - } & \text { Need } \\
\text { - } & \text { Because the family is in the same business } \\
\text { - } & \text { Formal education: university and technical } \\
\text { - } & \text { Age }\end{array}$ & $\begin{array}{l}\text { Urban settings - } \\
\text { intermediate cities } \\
\text { (Chile) }\end{array}$ \\
\hline
\end{tabular}

Source: Own elaboration based on mentioned authors.

For the factorial analysis, the study considers a set of variables aiming to identify the most important motivating 
factors through the reduction of such factors, as presented in Table 3, for later use of the regression model and verification of how these factors influence the informal trade activity of a merchant engaged in the commercialization of products or services.

\section{Results}

\subsection{Demographic Factors of The Informal Merchant}

Research results show that people who engage in informal commerce are $74.8 \%$ female and $25.2 \%$ male. Between the ages from 27 to 64 in $81.94 \%$, from 15 to 26 years in $14.52 \%, 65$ and older in $3.55 \%$, which means that women are the ones developing this informal activity, who end up considering it as a source of employment and income generation. Likewise, those engaged in informal commerce are married in $65.2 \%$ and single in $15.5 \%$, divorced $8.1 \%$, free union $7.7 \%$ and widowers in $3.5 \%$. Families have an average number of four members. Most of them have primary level education (43.9\%), secondary education (42.6\%), and superior education (9.4\%). Individuals who engage in this activity mainly come from urban areas $(68.4 \%)$ and from the rural area $(31.6 \%)$.

\subsection{Economic Factors of the Informal Merchant}

An informal merchant for the sale of products or services obtains different ranges of incomes, where, $82.6 \%$ is in the range of 1 to 500 US\$; $11.6 \%$ from 501 to 1000 US\$; $4.8 \%$ from 1001 US\$ to 1500 US\$; $0.6 \%$ from 1501 US\$ to 2000 US\$, and $0.3 \%$ more than 2000 US\$; being the average of 1245 US\$. This activity is done in different ways: personal initiative $75.5 \%$, family $23.2 \%$, and in partnership $1.3 \%$., as shown in Figure 2 and Figure 3.

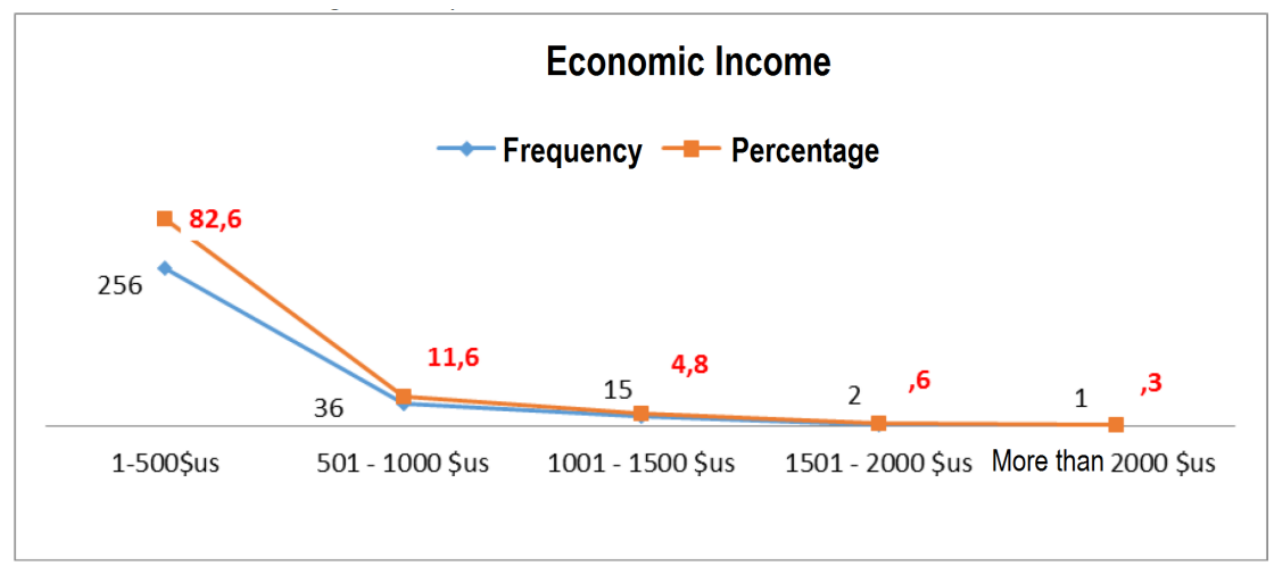

Figure 2. Economic income of merchants

Source: Own elaboration based on a survey conducted to informal merchants in the city of Riobamba, 2019.

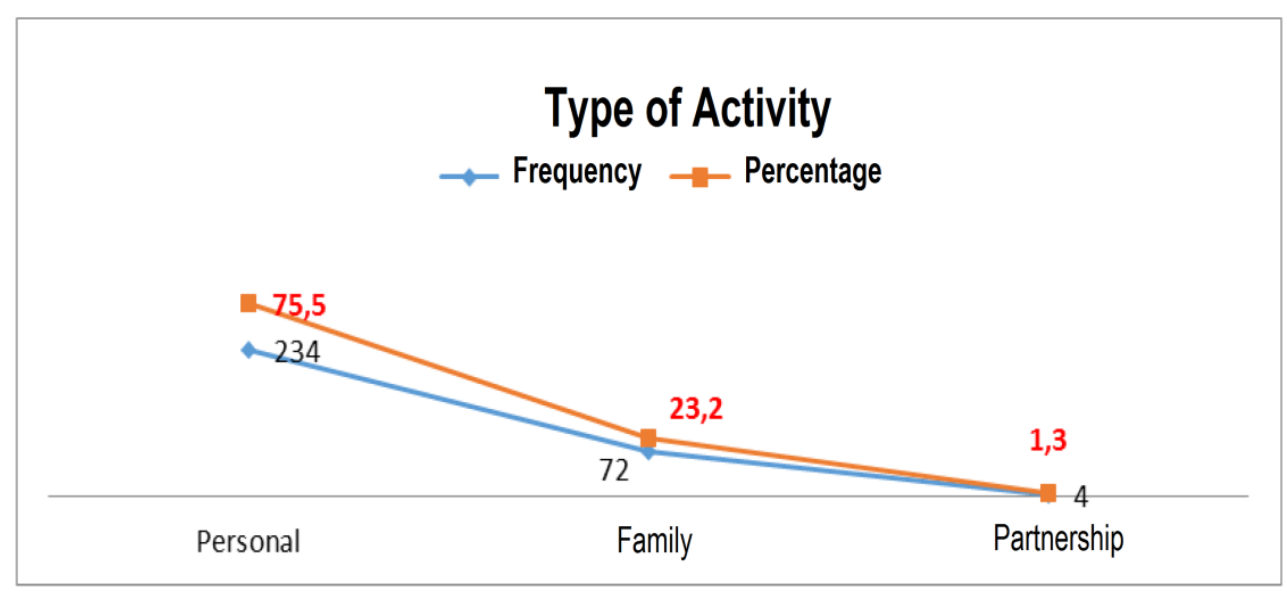

Figure 3. Type of activity

Source: Own elaboration based on a survey conducted to informal merchants in the city of Riobamba, 2019. 


\subsection{Commercialization Factors}

The type of activity done by the informal merchant is varied, commercialization of produce $15.5 \%$; purchase and sale of goods $83.2 \%$, and services in $1.3 \%$. Also, merchants commercialize their products in different ways, walking $21.6 \%$; home delivery $1.9 \%$; in vehicles $1.6 \%$; in improvised sale-point in the public market $65.8 \%$; in a permanent street sale-point $7.1 \%$; in a home-shop and in a house-room for exclusive use $0.3 \%$; in other house-rooms $0.3 \%$ and; others $1.3 \%$; identifying that informal merchants market their products through improvised sale-points in markets, as shown in Table 3.

Table 3. Ways of products commercialization

\begin{tabular}{lcc}
\hline Ways of commercialization & Frequency & Percentage \\
\hline Walking & 67 & 21.6 \\
Home delivery & 6 & 1.9 \\
In vehicles & 5 & 1.6 \\
In improvised sale-point in the public market & 204 & 65.8 \\
In a permanent street sale-point & 22 & 7.1 \\
In a home-shop and in a room for exclusive use & 1 & .3 \\
In other house-rooms & 1 & .3 \\
Others & 4 & 1.3 \\
Total & 310 & 100.0 \\
\hline
\end{tabular}

Source: Own elaboration based on a survey conducted to informal merchants in the city of Riobamba, 2019.

\subsection{Commercial Factors}

Research results show that reasons for merchants to start an informal activity were mostly that they wanted to be independent (26.8\%); necessity (24.8\%); did not find a formal job (24.8\%), as shown in Table 4.

Table 4. Reasons to start a business or activity

\begin{tabular}{lcc}
\hline Reasons & Frequency & Percentage \\
\hline Did not find a formal job & 77 & 24.8 \\
Higher incomes & 24 & 7.7 \\
Want to be independent & 83 & 26.8 \\
Family tradition & 31 & 10.0 \\
More family members & 4 & 1.3 \\
Only in seasons & 13 & 4.2 \\
Necessity & 77 & 24.8 \\
Others & 1 & .3 \\
Total & 310 & 100.0 \\
\hline
\end{tabular}

Source: Own elaboration based on a survey conducted to informal merchants in the city of Riobamba, 2019.

Likewise, data show that people start an informal commercial activity through the purchase and sale of goods is because: 1) they did not find a stable/formal job (83\%); 2) necessity $(81 \%) ; 3)$ independence $(89 \%)$, as shown in Table 5 . 
Table 5. Cross table-type of activity and reasons for starting an informal business activity

\begin{tabular}{|c|c|c|c|c|c|c|c|c|}
\hline \multirow[b]{2}{*}{$\begin{array}{l}\text { Reasons for starting a } \\
\text { business activity }\end{array}$} & \multicolumn{6}{|c|}{ Type of activity } & \multirow[b]{2}{*}{ Total } & \multirow[b]{2}{*}{ Total $\%$} \\
\hline & $\begin{array}{c}\text { Commerc } \\
\text { ialization } \\
\text { of } \\
\text { produce }\end{array}$ & $\begin{array}{c}\text { Commercializ } \\
\text { ation of } \\
\text { produce }(\%)\end{array}$ & $\begin{array}{l}\text { Purchase } \\
\text { and sale of } \\
\text { goods }\end{array}$ & $\begin{array}{c}\text { Purchase } \\
\text { and sale } \\
\text { of goods } \\
\quad \% 9\end{array}$ & $\begin{array}{l}\text { Services } \\
\text { Delivery }\end{array}$ & $\begin{array}{c}\text { Services } \\
\text { Delivery } \\
(\%)\end{array}$ & & \\
\hline $\begin{array}{l}\text { Did not find a formal } \\
\text { job }\end{array}$ & 10 & $13 \%$ & 64 & $83 \%$ & 3 & $4 \%$ & 77 & $100 \%$ \\
\hline Higher incomes & 3 & $13 \%$ & 21 & $88 \%$ & 0 & $0 \%$ & 24 & $100 \%$ \\
\hline $\begin{array}{l}\text { Want to be } \\
\text { independent }\end{array}$ & 9 & $11 \%$ & 74 & $89 \%$ & 0 & $0 \%$ & 83 & $100 \%$ \\
\hline Family tradition & 9 & $29 \%$ & 22 & $71 \%$ & 0 & $0 \%$ & 31 & $100 \%$ \\
\hline More family members & 2 & $50 \%$ & 2 & $50 \%$ & 0 & $0 \%$ & 4 & $100 \%$ \\
\hline Only in seasons & 1 & $8 \%$ & 12 & $92 \%$ & 0 & $0 \%$ & 13 & $100 \%$ \\
\hline Necessity & 14 & $18 \%$ & 62 & $81 \%$ & 1 & $1 \%$ & 77 & $100 \%$ \\
\hline Others & 0 & $0 \%$ & 1 & $100 \%$ & 0 & $0 \%$ & 1 & $100 \%$ \\
\hline Total & 48 & $15 \%$ & 258 & $83 \%$ & 4 & $1 \%$ & 310 & $100 \%$ \\
\hline
\end{tabular}

Source: Own elaboration based on a survey conducted to informal merchants in the city of Riobamba, 2019.

This means informal trade in cities is mainly motivated by unemployment, independence and necessity; and commercialization of purchased goods, demonstrating this way hypothesis 1 .

\subsection{Application of Factor Analysis to Identify Motivating Factors}

Kaiser Meye Olkin index $-\mathrm{KMO}=0.666$ indicates that the factorization model is relevant and Bartlelt's test shows that the model is adequate to explain the data. Matrix principal components results show that total factors used (26 factors) can be reduced to nine motivating factors that influence people to start an informal business activity. In addition, according to the variance matrix, nine reduced factors explain $63.77 \%$ of reasons. This reduction makes possible to identify the most important motivating factors of informal trade activity in the city of Riobamba.

For factorization, principal components and the extraction method were used: Varimax with Kaiser Normalization, 9 being factors extracted, as shown in Table 6.

These factors - according to the factor model - are related to: 1) Spatial factor, such as the place where informal trade activity takes place; 2) Regulatory, spatial and political regulation factor; 3) spatial regulation factor: 4) Economic factor, as the means to achieve a source of income; 5) Geographical factor, such as residence; 6) Marital status factor; 7) Educational and economic factor; 8) Ethnic factor; 9) Age factor.

Table 6. Results of the factor analysis-component matrix

\begin{tabular}{|c|c|c|c|c|c|c|c|c|c|c|}
\hline & \multicolumn{10}{|c|}{ Rotated Component Matrix ${ }^{a}$} \\
\hline & \multicolumn{9}{|c|}{ Component } & \multirow{2}{*}{$\begin{array}{c}\text { Communality } \\
\text { Extraction } \\
\end{array}$} \\
\hline & 1 & 2 & 3 & 4 & 5 & 6 & 7 & 8 & 9 & \\
\hline Age & -.105 & -.051 & -.062 & .004 & -.041 & -.628 & .018 & .571 & .065 & .744 \\
\hline Marital status & .141 & -.052 & .050 & .195 & .003 & .616 & -.059 & .193 & .302 & .575 \\
\hline Ethnic identification & -.081 & -.021 & .062 & .020 & -.134 & .075 & -.014 & .741 & -.014 & .584 \\
\hline Zone & .099 & -.023 & -.014 & -.002 & .859 & -.104 & -.013 & -.006 & -.082 & .767 \\
\hline Residence & .025 & .021 & .017 & .045 & .863 & .038 & .003 & -.137 & .103 & .779 \\
\hline Family members or responsibility & .127 & -.128 & .006 & .116 & .132 & -.520 & -.224 & -.078 & -.009 & .390 \\
\hline Schooling & -.021 & .195 & -.087 & -.077 & -.014 & .212 & .593 & -.217 & -.229 & .548 \\
\hline Economic income & .017 & -.178 & .023 & .099 & .054 & .095 & .743 & .103 & -.002 & .617 \\
\hline $\begin{array}{l}\text { Place. premises or establishment has potable } \\
\text { water service }\end{array}$ & .877 & .004 & .012 & .009 & -.021 & -.036 & .067 & -.155 & .031 & .800 \\
\hline $\begin{array}{l}\text { Place. premises or establishment has a drainage } \\
\text { service }\end{array}$ & .759 & .011 & .060 & .085 & .021 & .019 & -.039 & -.240 & .177 & .679 \\
\hline
\end{tabular}




\begin{tabular}{|c|c|c|c|c|c|c|c|c|c|c|}
\hline $\begin{array}{l}\text { Place. premises or establishment has electricity } \\
\text { services }\end{array}$ & .747 & -.075 & -.078 & .135 & .082 & -.119 & -.156 & .106 & -.061 & .648 \\
\hline $\begin{array}{l}\text { Place. premises or establishment has telephone } \\
\text { services }\end{array}$ & .598 & .259 & .118 & -.019 & .086 & .220 & -.017 & .062 & -.028 & .500 \\
\hline Commercialization investment & -.281 & .134 & .017 & -.016 & -.104 & -.320 & .554 & .028 & .234 & .572 \\
\hline Membership in an association & .073 & .012 & -.041 & -.063 & .025 & .116 & -.030 & -.046 & .871 & .787 \\
\hline $\begin{array}{c}\text { Believes that informal trade activity allows } \\
\text { survival. }\end{array}$ & .126 & .162 & -.005 & .849 & -.048 & .037 & -.072 & -.041 & .065 & .777 \\
\hline $\begin{array}{l}\text { Believes that informal trade activity allows } \\
\text { covering the basic needs. }\end{array}$ & .020 & .097 & .083 & .884 & -.027 & .077 & .094 & .024 & -.010 & .815 \\
\hline $\begin{array}{l}\text { Believes that informal trade activity allows } \\
\text { reducing migration. }\end{array}$ & .042 & -.079 & .253 & .724 & .157 & -.101 & .006 & .068 & -.115 & .648 \\
\hline $\begin{array}{l}\text { Believes that informal trade activity is an } \\
\text { answer to the lack of distribution spaces. }\end{array}$ & -.060 & .059 & .612 & .207 & .013 & -.022 & -.241 & -.065 & .222 & .536 \\
\hline $\begin{array}{l}\text { Believes that informal trade activity is an } \\
\text { answer to population grow. }\end{array}$ & .114 & .207 & .499 & .260 & -.166 & -.212 & .196 & .095 & .238 & .549 \\
\hline $\begin{array}{l}\text { Believes that informal trade activity is an } \\
\text { answer to ignorance of tax regulation. }\end{array}$ & .060 & .114 & .766 & .058 & .100 & -.009 & .091 & .107 & -.162 & .663 \\
\hline $\begin{array}{l}\text { Believes that informal trade activity results } \\
\text { from ignorance of public use regulations. }\end{array}$ & .011 & .043 & .832 & .002 & -.022 & .137 & -.008 & .047 & -.052 & .719 \\
\hline $\begin{array}{l}\text { Believes that informal trade activity does not } \\
\text { help formal trade. }\end{array}$ & -.156 & .299 & .237 & .036 & .054 & .294 & .034 & .427 & -.116 & .457 \\
\hline $\begin{array}{l}\text { Believes that informal trade activity results } \\
\text { from lack of local policies. }\end{array}$ & .074 & .530 & .438 & .058 & -.106 & .100 & -.068 & -.017 & -.118 & .522 \\
\hline $\begin{array}{l}\text { Believes that belonging to an association helps } \\
\text { you develop your activity in a formal way. }\end{array}$ & .034 & .706 & .052 & .190 & .203 & -.023 & -.029 & -.027 & -.063 & .586 \\
\hline $\begin{array}{l}\text { Considers it important to become a formal } \\
\text { merchant. }\end{array}$ & .011 & .778 & .108 & -.014 & -.034 & .025 & -.012 & .051 & .059 & .626 \\
\hline Consider it important to pay taxes. & .035 & .813 & .017 & .011 & -.102 & .047 & .093 & -.006 & .071 & .690 \\
\hline
\end{tabular}

Extraction method: principal component analysis.

Rotation method: Varimax with Kaiser normalization. a

a. Rotation converged in 12 iterations.

Source: Own elaboration based on a survey conducted to informal traders in the city of Riobamba, 2019.

\subsection{Application of Linear Regression to Identify the Degree of Influence of Motivating Factors in Informal Trade Activity}

Likewise, the linear regression model was applied to verify the degree of influence of the motivating factors, identified using the factorial model, in the development of the informal trade activity. In this case, the linear regression model 1 is represented next:

$$
\mathrm{Y}=\mathrm{b}_{\mathrm{o}}+\mathrm{b}_{1} \mathrm{x}_{1}+\mathrm{b}_{2} \mathrm{x}_{2}+\mathrm{b}_{3} \mathrm{x}_{3}+\ldots+\mathrm{b}_{\mathrm{n}} \mathrm{x}_{\mathrm{n}}+\mathrm{u}
$$

Informal trade activity (Dependent variable) $=\mathrm{b}_{0}+\mathrm{b}_{1} \times$ Age $+\mathrm{b}_{2} \times$ Marital Status $+\mathrm{b}_{3} \times$ Ethnic Identification $+\mathrm{b}_{4}$ $\mathrm{x}$ Zone $+\mathrm{b}_{5} \mathrm{x}$ Economic income $+\mathrm{b}_{6} \mathrm{x}$ Location $+\mathrm{b}_{7} \mathrm{x}$ necessity $+\mathrm{b}_{8} \mathrm{x}$ Ignorance of public use regulation $+\mathrm{b}_{9} \mathrm{x}$ Taxes (independent variables).

Results show that informal trade activity done by merchants through walking, home delivery, in own vehicles, in improvised sale-point, in a permanent street sale-point, in a home-shop, in a house-room, and others, depend on the factors related to: age, marital status, ethnicity, zone, economic income, location, necessity, ignorance of public spaces regulation, taxes (sig. 0.000) and these variables explain in $8.8 \%\left(\mathrm{R}^{2}=0.088\right)$ with a ratio between the variables at $29.7 \%(\mathrm{R}=0.297)$. However, the following is identified:

Factors of model 1 do not influence (Sig. 0.160) on the type of activity developed by the informal trader/merchant, that is, on the commercialization of; 1) produce commercialization; 2) purchase and sale of goods; 3) services delivery. In the same way, the commercial activity carried out by informal merchants as a person, family or partnership does not depend on these 9 factors (Sig. 0.818); as shown in Figure 4. 

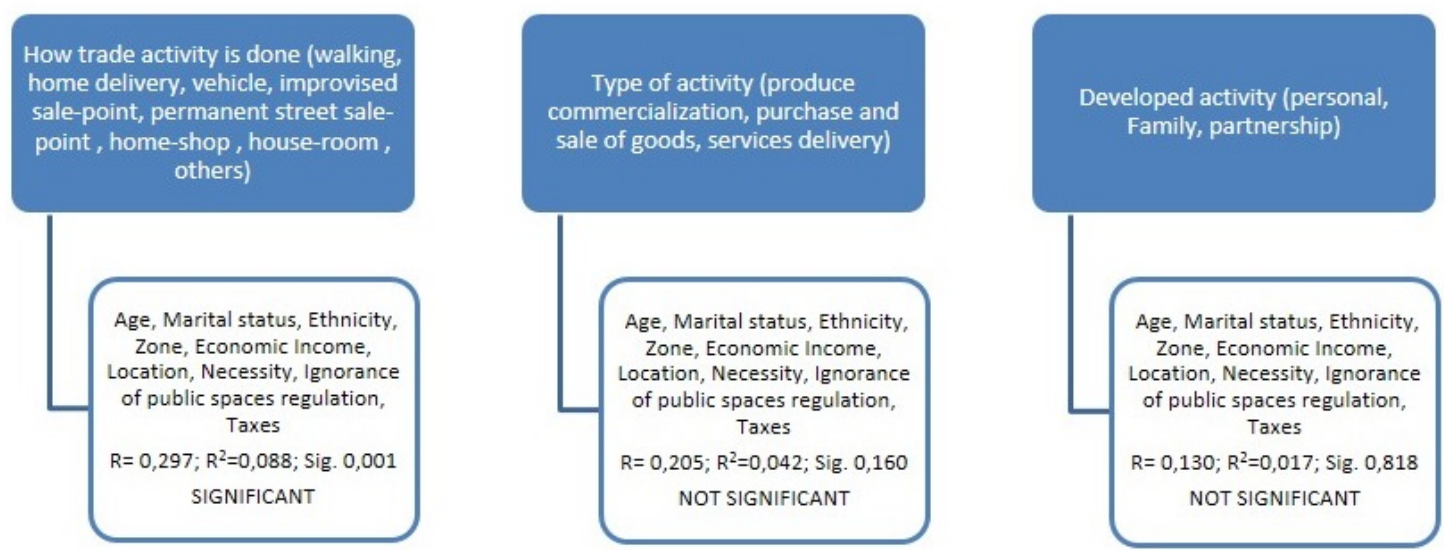

Figure 4. Relationship between the motivating factors and the informal trade activity of the merchant

Source: Own elaboration based on a survey conducted to informal merchants in the city of Riobamba, 2019.

Therefore, it can be stated that age, marital status, ethnicity, zone, economic income, location, necessity, ignorance of public spaces regulation, taxes are motivating factors that influence informal trade, confirming hypothesis 2; however, they do not influence the form or type of commercial activity (H3).

\subsection{Motivating Factors That Significantly Influence Informal Trade Activity}

However, in order to know the weight and contribution of demographic, geographical, economic, social, and commercialization factors to commercial activity rationale/explanation, the linear regression by conglomerated factors was applied. To begin, demographic and geographical factors were considered, to know about variables degree explanation for this factor, called model 1. After obtaining the first model result, to see if explanation degree of these factors increases or decreases, economic factor and availability variables were included, becoming model 2. Finally, social, regulatory and marketing factors were included into model 2, resulting into model 3. Likewise, to know the degree of contribution to the explanation, social, regulatory and commercialization factors were considered separately. Such models are presented in Table 7.

Table 7. Variables of the demographic and geographical, economic, availability, social, regulatory and commercialization factor

\begin{tabular}{|c|c|}
\hline $\begin{array}{l}\text { Dependent } \\
\text { variables }\end{array}$ & $\begin{array}{l}\text { Independent variables } \\
\text { GENERAL MODEL: } \mathrm{Y}=\mathrm{b}_{\mathrm{o}}+\mathrm{b}_{1} \mathrm{x}_{1}+\mathrm{b}_{2} \mathrm{x}_{2}+\mathrm{b}_{3} \mathrm{x}_{3}+\ldots+\mathrm{b}_{\mathrm{n}} \mathrm{x}_{\mathrm{n}}+\mathrm{u}\end{array}$ \\
\hline \multirow[b]{2}{*}{$\begin{array}{l}\text { V1. Informal } \\
\text { trade activity }\end{array}$} & MODEL 1: Demographic and geographic variables \\
\hline & $\begin{array}{l}\mathrm{b} 0+\mathrm{b}_{1} \times \text { Economic Income }+\mathrm{b}_{2} \times \text { Ethnic Identification }+\mathrm{b}_{3} \times \text { Marital Status }+\mathrm{b}_{4} \times \text { Zone }+\mathrm{b}_{5} \times \text { Location }+\mathrm{b}_{6} \times \text { Necessity } \\
+\mathrm{b}_{7} \times \text { Ignorance of public spaces regulation }+\mathrm{b}_{8} \times \text { Taxes }\end{array}$ \\
\hline \multirow{2}{*}{$\begin{array}{l}\text { V2. Type of } \\
\text { activity }\end{array}$} & MODEL 2: Economic variables and availability \\
\hline & Model $1+\mathrm{B}_{9} \mathrm{X}$ Daily economic income from the sale of their products $+\mathrm{B}_{10} \mathrm{x}$ time economic activity is being conducted \\
\hline \multirow{3}{*}{$\begin{array}{l}\text { V3. Form of } \\
\text { activity }\end{array}$} & MODEL 3. Social, regulatory and commercial variables \\
\hline & $\begin{array}{l}\text { MODEL 1+ MODEL } 2+b_{11} \times \text { Survive }+b_{12} \times \text { Cover basic needs }+b_{13} \times \text { Migration reduction }+b_{14} \times \text { Lack of spaces }+b_{15} \times \\
\text { population growth }+b_{16} \times \text { ignorance of public use regulation }+b_{17} \times \text { does not help formal trade }+b_{18} \times \text { lack of local } \\
\text { policies }+b_{19} \times \text { Membership in an association }+b_{20} \times \text { becoming a formal merchant }+b_{21} \times \text { taxes payment. }\end{array}$ \\
\hline & MODEL 4. Social, regulatory and commercial variables only \\
\hline
\end{tabular}

Source: Own elaboration based on a survey conducted to informal merchants in the city of Riobamba, 2019.

\subsubsection{Demographic and Geographical Factors}

The results of model 1 application show that there is dependence on variable 1, but it is not the same for variables 2 and 3, as seen in Figure 5. Which means that demographic and geographical factors influence in $0.7 \%\left(\mathrm{R}^{2}=\right.$ 0.079) to the informal trade activity, which is not the same for type (sig. 0.144) and the form (Sig. 0.322), as observed in Figure 5. 


\subsubsection{Economic and Availability Factors}

However, this degree of explanation increases to $13.9 \%\left(\mathrm{R}^{2}=0.139\right)$ and it is significant (Sig. 000) when adding economic and availability factor variables to how trade activity is conducted (model 2). On the other hand, there is no contribution of this factor to the type and form informal trade activity is done (see Figure 5).

\subsubsection{Social, Regulatory and Commercialization Factors}

In return, when factors of model 1 and 2 include the social, regulatory and commercialization factor (model 3), there is an increase to $19.9 \%$ in the explanation of how to develop informal trade, since there is a $44.7 \%$ relationship between variables and dependence (sig. 0.000). Likewise, it can be seen that the type of activity can be explained in $0.9 \%\left(R^{2}=0.090\right.$; Sig. 0.000$)$ and in $12.1 \%\left(R^{2}=0.121\right.$; Sig. 0.024$)$ on the form the informal trade activity is conducted by merchants around markets.

Finally, model 4 shows whether social, regulation, and commercialization factor variables contribute - separately - to model 1 and model 2. Results show that if only these variables are considered, separately, they do not contribute significantly in the explanation: 1) of the type and 2) the form of informal trade (sig.> = 0.05) (see Figure 5), being necessary to consider the demographic, geographical, availability, economic, social, regulatory and commercialization factor variables, since in this way, the most important variables become informal trade motivating factors.

On the other hand, when it comes to explaining the reasons for informal trade, it can be seen that social, regulatory and commercialization factors are important since they contribute $0.9 \%$ in the explanation, existing a dependency relationship (sig. 0.002). Demonstrating this way hypothesis 4 and 5.
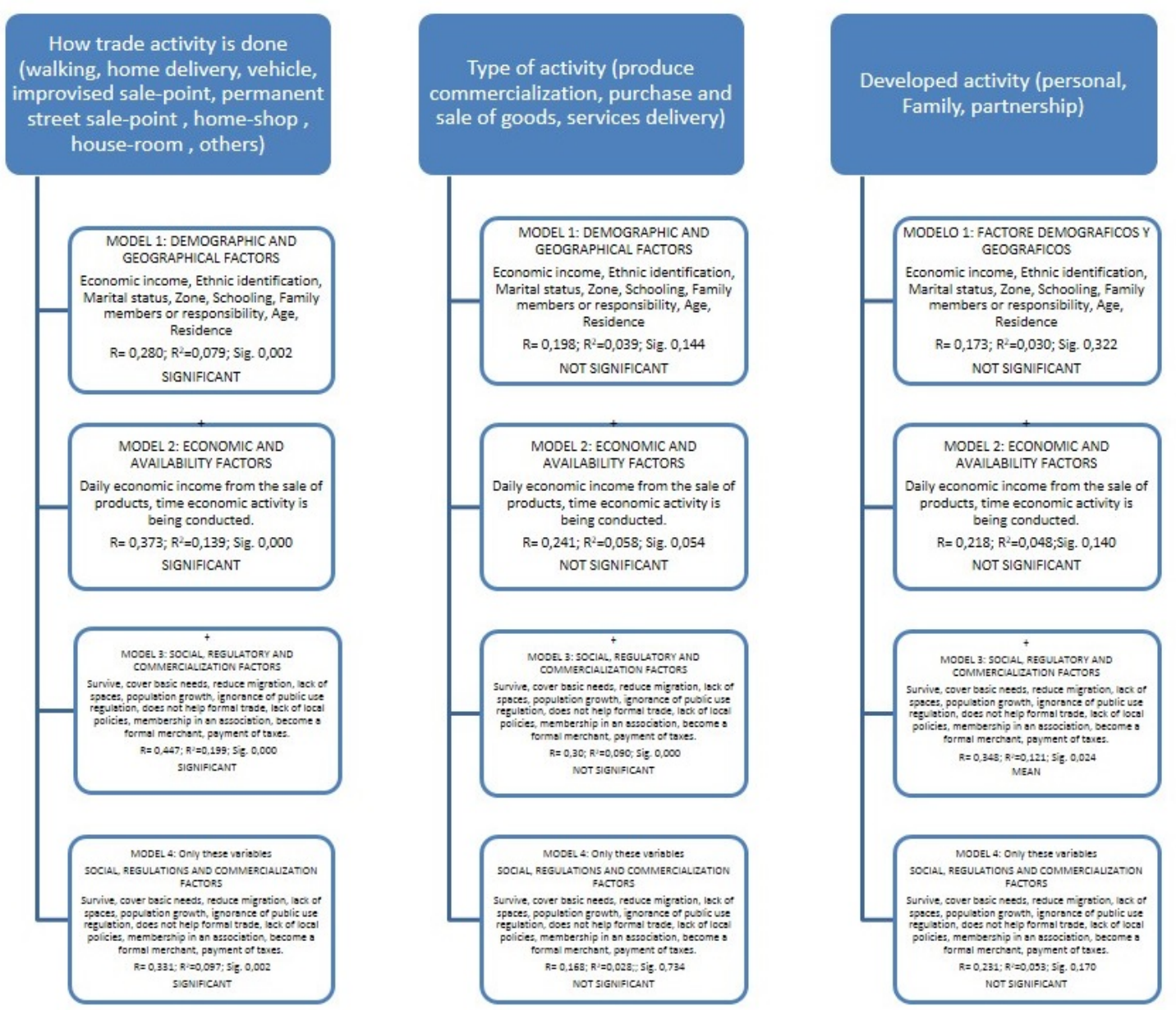

Figure 5. Motivating factors that influence the how, type and form informal trade activity is conducted by merchants

Source: Own elaboration based on a survey conducted to informal merchants in the city of Riobamba, 2019. 


\section{Conclusions}

Informal trade activity is not directly related to age, marital status, economic income and income level, but to the contribution of other factors: such as ethnicity, location, necessity, ignorance of public spaces regulation, and taxes; being these, motivating factors that significantly influence the informal trade activity done by merchants.

The type (commercialization of produce, purchase and sale of goods, service delivery) and the form (personal, family, partnership) in which informal trade is conducted does not depend on motivating factors, such as, age, marital status, ethnicity, zone, economic income, location, necessity, ignorance of public spaces regulation, and taxes. Unemployment, independence and necessity are factors that positively affect the start of an informal activity, such as trade.

Informal trade activity conducted by merchants/traders through walking, home delivery, in vehicles, improvised sale-point, permanent street sale-point, home-shop, house-room, and others, depend on demographic, geographical, economic, availability, social, regulatory, and commercialization factors, but not the type or form of trade.

There are no significant differences between motivating factors identified in metropolitan cities compared to an intermediate city, because most studies reflect these identified factors; however, there are some differential elements, such as, migration, population growth and lack of spaces.

\section{References}

Adasme, S. (2017). Comercio informal en Chile. 6 claves para el debate. Retrieved from https://www.ieschile.cl/wp-content/uploads/2017/03/Claves-comercio-informal-en-Chile-FINAL.pdf

Alvarez, A., Goméz, E., Manjarrez, A., Orozco, D., \& Padilla, K. (2015). Comercio informal y los factores incidentes en este. Revista Latinoamericana de Ciencias Sociales y Desarrollo Humano. Retrieved from https://www.academia.edu/23385928/COMERCIO_INFORMAL_Y_LOS_FACTORES_INCIDENTES_E N_ESTE

Boza, J. (2018). Comercio informal y su incidencia en la economía del Cantón Quevedo. Revista ARJE. Revista de Postgraado FaCE-UC, 12(22), 415-426. Retrieved from http://arje.bc.uc.edu.ve/arje22/art49.pdf

Bustamante, M., Díaz, R., \& Villareal, P. (2009). Economía informal: Un análisis al comercio ambulante de la región del Maule, Chile. Revista Forum Empresarial, 14(1), 37-61. https://doi.org/10.33801/fe.v14i1.3407

Castillo-Garcia, W. (2014). Comercio informal. Retrieved from https://es.calameo.com/read/003961067dcac285d004f

De Souza, M., \& Bustos, A. (2017). El comercio informal de calle en las comunas Santiago y Concepción. Revista Urbano, 35, 58-73. https://doi.org/10.22320/07813607.2017.20.35.05

ENEMDU, INEC. (2018). Tabulados Encuesta Nacional de Empleo, Desempleo y Subempleo (ENEMDU). Retrieved from https://www.ecuadorencifras.gob.ec

Figueroa-Sierra, N. (2012). La elusión y evasión fiscal. Revista Avances, 14, 374.

Henríquez, J. Y. (2015). Evasión tributaria: atentado a la equidad. Revista de estudios tributarios, 13, 171.

Hernández, M., \& De la Roca, J. (2006). Evasión tributaria e informalidad en el Perú. Revista Economía y Sociedad, 62, 65-72. $\quad$ Retrieved from http://www.cies.org.pe/sites/default/files/files/otros/economiaysociedad/09_hernandez.pdf

ILO. (2012). World of Work Report 2012. Better jobs for a better economy. Geneva. Retrieved from https://www.ilo.org/wcmsp5/groups/public/---dgreports/---dcomm/---publ/documents/publication/wcms_17 9453.pdf

ILO. (2014). World of Work Report 2014. Developing with jobs. Geneva. Retrieved from https://www.ilo.org/wcmsp5/groups/public/---dgreports/---dcomm/documents/publication/wcms_243961.pd $\mathrm{f}$

Jimenéz, A., \& Martinéz-Pardo, A. (2013). La economía sumergida en España (Documento de Trabajo $\left.N^{o} 4\right)$. Madrid: Fundación de Estudios Financieros.

León, M. O. (2014). ELUSIÓN O EVASIÓN FISCAL. Revista Iberoamericana de Contaduría, Economía y Administración, 5.

Martínez, D., Pérez, A., Pat, L., Caamal, I., Franco, M., \& García, L. (2019). El sector informal en la ciudad de México. estudio de la Delegación Iztapalapa. Revista de Alimentación Contemporánea y Desarrollo 
Regional. Estudios Sociales, 29(53), 1-22. https://doi.org/10.24836/es.v29i0.725

Merchán, M., \& Velásquez, N. (2015). La evasión y elusión tributaria de las MYPE en las empresas del sector comercio-rubro abarrotes del distrito de Chimbote, 2014. In Crescendo, Derecho, 19-27.

Moreira, M., \& Pilco, B. (2016). Análsis de las características del sector informal en la Provincia de los Rios del Ecuador. Revista Publicando, 3(7), 398-416. Retrieved from https://revistapublicando.org/revista/index.php/crv/article/view/128

Ochoa, M. (2014). Elusión o evasión fiscal. Revista Iberoamericana de Contaduría, Economía y Administración, 3(5), 18-46. https://doi.org/10.23913/ricea.v3i5.19

OIT. (2002). Panorama Laboral 2002. América Latina y el Caribe. Retrieved from https://www.ilo.org/wcmsp5/groups/public/---americas/---ro-lima/documents/publication/wcms_187550.pdf

OIT. (2014). Panorama Laboral 2014. América Latina y el Caribe. Perú. Retrieved from https://www.ilo.org/wcmsp5/groups/public/---americas/---ro-lima/documents/publication/wcms_325664.pdf

OIT. (2016). Panorama Laboral 2016. América Latina y el Caribe. Lima. Retrieved from https://www.ilo.org/wcmsp5/groups/public/---americas/---ro-lima/documents/publication/wcms_537803.pdf

OIT. (2018). Mujeres y hombres en la economía informal: Un panorama estadístico. En Ingles Women and men in the informal economy: A statistical picture. Ginebra: OIT _ILO. Retrieved from https://www.ilo.org/wcmsp5/groups/public/---dgreports/---dcomm/documents/publication/wcms_635149.pd $\mathrm{f}$

OIT. (2019). Perspectivas sociales y del empleo en el mundo. Tendencias 2019. Retrieved from https://www.ilo.org/wcmsp5/groups/public/---dgreports/---dcomm/---publ/documents/publication/wcms_67 0569.pdf

Ordóñez, A. (2010). Evasión tributaria y redistribución de los ingresos: enfoque de un modelo de equilibrio general tributario (Master's thesis, Quito: FLACSO sede Ecuador).

Paredes, P. (2016). Evasión tributaria vs. Mecanismos de control implementados por la administración pública. Retos, 181-198. https://doi.org/10.17163/ret.n12.2016.04

Quejada, R., Yanez, M., \& Cano, K. (2014). Determinantes de la informalidad laboral:un análisis para Colombia. Revista Investigación y Desarrolllo, 22(1), 126-145. Retrieved from https://www.academia.edu/19595127/Determinantes_de_la_informalidad_laboral_Un_an\%C3\%A1lisis_par a_Colombia

Quintanilla, E. (2014). Repositorio Académico USMP. Obtenido de Repositorio Académico USMP. Retrieved from http://www.repositorioacademico.usmp.edu.pe/bitstream/usmp/1106/1/quintanilla_ce.pdf

Quispe, G., Tapia, M., Ayaviri, D., Villa, M., Borja, M., \& Lema, M. (2018). Causas del comercio informal y la evasión tributaria en ciudades intermedias. Espacios, 4.

Real, M., \& Navarrete, C. (2018). Los paraísos fiscales y la elusion tributaria en el Ecuador. Dilemas Contemporáneos: Educación, Política y Valores, 1-15.

Robles, D., \& Martinez, M. (2018). Determinantes principales de la informalidad: un análisis regional para México. Revista Región y Sociedad, 30(71), 135. https://doi.org/10.22198/rys.2018.71.a575

Rodriguez, E., De la Torre, H., \& Regla, S. (2016). Características y determinantes de la informalidad laboral en México. Revista Estudios Regionales en Economía, Población y Desarrollo. Cuadernos de Trabajo de la UACJ, 1-39. Retrieved from $\mathrm{http}: / /$ erevistas.uacj.mx/ojs/index.php/estudiosregionales/article/view/1536/1354

Romero, V. (2018). Las brechas de recaudación tributaria del impuesto al valor agregado en el sector societario y su impacto en el presupuesto general del estado ecuatoriano. Observatorio de la Economía Latinoamericana.

Rua, W. ( 2016). El concepto de evasión y elusión.

Sandoval Betancour, G. (2014). La informalidad laboral: causas generales. Equidad y desarrollo, 1(22), 9-45. https://doi.org/10.19052/ed.3247

Teja, R., \& López, N. (2013). Comercio informal: Un estudio en el Municipio de Texcoco, Edo. de México. Revista Internacional Administración y Finanzas, 6(4), 52-72. 
Villamil, R. (2014). La economía informal: Causas, consecuencias y ejes de solución. Lima: AAPERHU-CENTRUM Católica.

Yañez, J. (2015). Evasión tributaria: atentado a la equidad. Revista Estudios tributario, 13, 171-206. Retrieved from https://revistaestudiostributarios.uchile.cl/index.php/RET/article/view/39874/41444

\section{Copyrights}

Copyright for this article is retained by the author(s), with first publication rights granted to the journal.

This is an open-access article distributed under the terms and conditions of the Creative Commons Attribution license (http://creativecommons.org/licenses/by/4.0/). 